\title{
Research on the application of green GDP in environmental performance audit
}

\author{
Jinyu Tian \& Shuhua Wu
}

\begin{abstract}
North China Electric Power University, Department of Economics and Management, NCEPU, Baoding, Hebei, China
\end{abstract}

\section{KEYWORD: Green GDP;Environmental performance audit;Application}

\begin{abstract}
As a major branch of environmental audit, environmental performance audit occupies an important position in the environmental management system.At present, the environmental problem is becoming more and more serious.Can you find a way to the sustainable development has a relationship with the whole nation's rise and fall.One of the problems of environmental performance audit practice is that it is difficult to completely take the audit task of the reality of the situation. Therefore, exploring new environmental performance audit methods has become an academic frontier issues in the field.Based on the method of green GDP in the application of environmental performance auditing for content,this paper seeks solutions to resolve it, so as to provide beneficial discussion for the development of the field.
\end{abstract}

\section{INSTRUCTION}

With the rapid growth of the worldwide economy,environment pollution problem increases seriously and affects our life. Whether in the history of the world's ten biggest contamination or heat haze events in recent years, they are nature's wake-up call to us.Environmental performance audit is under the background of the adapt to the demand of The Times.

Environmental performance audit is a multidisciplinary cross at the forefront of the audit field.Studing of the field, a large number of scholars and experts at home and abroad to explore, and a series of achievements obtained.These studies around the definition of environmental performance audit, scope, criteria, methods, etc, in order to promote the development of practical work to create certain condition.About the connotation of environmental performance audit, scholars at home and abroad are from the auditor, audit contents, audit goal to generalize.The author thinks that, as part of the environment audit, environmental performance auditing is a blend of performance audit of the audit function at the same time.And environmental performance audit is the audit organ of the auditees related economic activities, environmental policies and regulations of the implementation, internal control system and so on economy, efficiency and effect of an audit.And at the end of the day is taking the supervision of the audit, evaluation and verification of a form of basic functions.

\section{Summary of method of green GDP}

Research on environmental performance audit, a big problem for the complicated world is how to break through all kinds of data indicators compared reasonable planning establishment unified dimension.Environment audit project audit object facing the difference in thousands ways.Such as water, atmosphere, soil, minerals, grassland, etc..and the internal control system and execution of policies and regulations.So, for the auditor, it is difficult to apply the existing audit methods to achieve ideal audit in full.Therefore, give full play to the multidisciplinary cross feature of environmental performance audit, the audit method of continuous imported from other areas, innovation as a way to solve this problem.Method of green GDP is one of them.

GDP is an abbreviation of gross domestic product,measuring of a country or region's economy during a given period of time in the produce of the value of all final goods and services.Method of green GDP, namely, on the basis of the traditional method of GDP to improve.The elements in the 
introduction environment, breakthrough ignore environmental elements the defects in traditional statistical caliber, enables the GDP to reflect the environmental impact of the total economic output, make more objective and comprehensive statistical indicators.

For the green GDP index calculation system research began in the 1970 s.The United Nations statistics, the world bank's environment ministry, national environmental protection agency (epa), etc are studied in the field.Issued by the United Nations in 1993 SEEA (integrated environmental and economic accounting system)has a profound influence in the field of study. The main bodies in the field research mainly for environmental protection are the national bureau of statistics, and some colleges and universities.Since the beginning of the 21st century, our country continuously introduce accounting system in the field of green GDP study research results and applied to practical calculation.Of these, the typical research achievements including the China resources environmental economic accounting system framework, etc.On GDP and green GDP accounting content, can be explained with the following formula:

$\mathrm{GDP}=$ Consumption + Private investment

+Government spending+Net exports

Green GDP=The traditional GDP-The cost of resource depletion-The cost of environmental degradation+Resources and environment to improve yield

To be sure, about the calculation of GDP, it has now formed a relatively unified point of view.And about green GDP accounting, there is no consistent.This article selects the above formula as the calculation basis of this article.With the deepening of research, the calculation formula of green GDP is not the first item only reduce gradually evolved into today's considering environmental improvements increased profits.

Value evaluation method of green GDP accounting system now is still a debate.Market valuation method, the actual market value method, recovery payments shall be used as part of the method,for solving the problem of value evaluation have played a role.This article will draw these methods to analyze.

\section{The application of method of green GDP research}

In this paper, based on the method of green GDP, choosing city A to carry on the empirical research,of research in the environmental performance auditing method provides referential ideas, perfecting the green GDP method application in practice.

City A is in southwest China inland, land area of more than 80000 square kilometers, A humid subtropical monsoon climate.City A is rich in water system, the important rivers which flow through are the Yangtze River, Jialing River, etc..At present, the city has formed the electronic information, automobile, equipment manufacturing and other billion industrial clusters.Agricultural rural and financial, business logistics, service outsourcing and other modern service industry is also developing rapidly.According to the EPS database, the city's total production value of 2009-2013 as shown in the following table:

Table 1. the 2009-2013 annual GDP of City A

\begin{tabular}{l|l|l|l|l|l}
\hline Time & 2009 & 2010 & 2011 & 2012 & 2013 \\
\hline $\begin{array}{l}\text { Gross domestic } \\
\text { product }\end{array}$ & 6530.01 & 7925.58 & 10011.37 & 11409.6 & 12656.69 \\
\hline
\end{tabular}

(Unit:Billion yuan)

(1)Resource depletion cost 
Table 2. the 2009-2013 Resource consumption reduction of City A

\begin{tabular}{c|l|l|l|l|l}
\hline Category & 2008 & 2009 & 2010 & 2011 & 2012 \\
\hline $\begin{array}{c}\text { Coal (Million } \\
\text { tons) }\end{array}$ & $\begin{array}{l}5272.7 \\
2\end{array}$ & $\begin{array}{l}5781.7 \\
2\end{array}$ & $\begin{array}{l}6396.9 \\
0\end{array}$ & $\begin{array}{l}7189.0 \\
0\end{array}$ & $\begin{array}{l}6750.0 \\
0\end{array}$ \\
\hline $\begin{array}{c}\text { Natural gas } \\
\text { (Million } \\
\text { cubic meters) }\end{array}$ & 48.75 & 49.47 & 56.42 & 61.80 & 70.98 \\
\hline $\begin{array}{c}\text { Oil (Million } \\
\text { tons) }\end{array}$ & 6.93 & 7.01 & 9.28 & 9.29 & 9.33 \\
\hline
\end{tabular}

In this paper, we use the net price method to measure the cost of resource consumption.The calculation formula is as follows:

Mineral resources price=The market price of the mineral products-Mineral deposit prospecting-Development transportation cost

After calculation, the recovery price of coal theory is 730000 yuan / ton.Natural gas recovery cost is 21730000 yuan / million cubic meters.Oil recovery cost is 4610000 yuan / ton. The calculation can draw the resource consumption reduction value table 3 :

Table 3. the 2009-2013 Resource consumption reduction of City A

(Unit:Billion yuan)

\begin{tabular}{c|l|l|l|l|l}
\hline Category & \multicolumn{1}{|c|}{2008} & \multicolumn{1}{c}{2009} & \multicolumn{1}{c|}{2010} & 2011 & 2012 \\
\hline Coal & $\begin{array}{l}384909 . \\
29\end{array}$ & $\begin{array}{l}422065 . \\
56\end{array}$ & $\begin{array}{l}466973 . \\
7\end{array}$ & 524797 & 492750 \\
\hline Natural gas & $\begin{array}{l}105933 . \\
75\end{array}$ & $\begin{array}{l}107498 . \\
31\end{array}$ & $\begin{array}{l}122600 . \\
66\end{array}$ & $\begin{array}{l}134291 . \\
4\end{array}$ & $\begin{array}{l}154239 . \\
54\end{array}$ \\
\hline Oil & 3194.73 & 3231.61 & 4278.08 & 4282.69 & 4301.13 \\
\hline
\end{tabular}

(2) Environmental degradation cost

Environmental degradation cost need consider the main factors : waste water, waste gas, solid waste, etc.. The actual emission values of the three types of emissions from City A of 2009-2013:

Table 4. the 2009-2013 Waste water discharge of City A

(Unit:Million tons)

\begin{tabular}{c|c|c|c|c|c}
\hline Category & 2008 & 2009 & 2010 & 2011 & 2012 \\
\hline $\begin{array}{c}\text { Industrial } \\
\text { wastewater }\end{array}$ & 67027 & 65684 & 45180 & 33954 & 30611 \\
\hline $\begin{array}{c}\text { Living } \\
\text { wastewater }\end{array}$ & 78086 & 81385 & $\begin{array}{l}82933 . \\
30\end{array}$ & $\begin{array}{l}97355 . \\
60\end{array}$ & $\begin{array}{l}101676 \\
.69\end{array}$ \\
\hline
\end{tabular}

After calculation, industrial wastewater and domestic wastewater treatment costs for industrial wastewater was 4 yuan / ton.Living wastewater treatment cost is 0.6 yuan / ton.The value is calculated as follows: 
Table 5. the 2009-2013 Waste water discharge of City A

(Unit:Million yuan)

\begin{tabular}{c|c|c|c|c|c}
\hline Category & 2008 & 2009 & 2010 & 2011 & 2012 \\
\hline $\begin{array}{c}\text { Industrial } \\
\text { wastewater }\end{array}$ & 268108 & 262736 & 180720 & 135816 & 122444 \\
\hline $\begin{array}{c}\text { Living } \\
\text { wastewater }\end{array}$ & $\begin{array}{l}46851.6 \\
0\end{array}$ & 48831 & $\begin{array}{l}49759.9 \\
8\end{array}$ & $\begin{array}{l}58413.3 \\
6\end{array}$ & $\begin{array}{l}61006.0 \\
1\end{array}$ \\
\hline
\end{tabular}

The emissions, solid waste emissions of City A are as follows:

Table 6. the 2009-2013 The emissions, solid waste emissions of City A (Unit:Million tons)

\begin{tabular}{c|l|l|l|l|l}
\hline Category & \multicolumn{1}{|c|}{2008} & 2009 & 2010 & 2011 & 2012 \\
\hline Sulfur dioxide & 78.24 & 74.61 & 71.94 & 58.69 & 56.48 \\
\hline Smoke dust & 23.66 & 18.96 & 18.92 & 17.37 & 17.52 \\
\hline Industrial solid waste & 149.00 & 150.00 & 134.00 & 24.15 & 5.00 \\
\hline
\end{tabular}

After calculation, the cost of governance of sulfur dioxide is 780 yuan / ton.Smoke dust and industrial solid waste management costs were 420 yuan / ton and 50 yuan / ton. The value of waste gas and solid waste is as follows:

Table 7. the 2009-2013 The emissions, solid waste emissions of City A

(Unit:Million yuan)

\begin{tabular}{c|c|c|c|c|c}
\hline Category & \multicolumn{1}{|c|}{2008} & \multicolumn{1}{c}{2009} & \multicolumn{1}{c|}{2010} & 2011 & 2012 \\
\hline Sulfur dioxide & 61027.20 & 58195.80 & 56113.20 & 45778.20 & 44054.40 \\
\hline Smoke dust & 9937.20 & 7963.20 & 7946.40 & 7295.40 & 7358.40 \\
\hline Industrial solid waste & 7450 & 7500 & 6700 & 1207.50 & 250 \\
\hline
\end{tabular}

(3)Resources and environment improvement

Table 8. the 2009-2013 Afforestation, afforestation area of City A

\begin{tabular}{c|c|c|c|c|c}
\multicolumn{7}{c}{ (Unit:Hectare) } \\
\hline Category & 2008 & 2009 & 2010 & 2011 & 2012 \\
\hline Afforestation & 106120 & 95726 & 255235 & 244644 & $\begin{array}{l}300747 \\
0\end{array}$ \\
\hline Cultivate forest & 387840 & 299471 & 314726 & 372116 & 406894 \\
\hline
\end{tabular}

To estimate the price of timber forest, the price of timber forest is 750 yuan / ha.The values are as follows: 
Table 9. the 2009-2013 Afforestation, forest value of City A

(Unit:Million yuan)

\begin{tabular}{c|l|l|l|l|l}
\hline Category & 2008 & 2009 & 2010 & 2011 & 2012 \\
\hline Afforestation & 7959 & $\begin{array}{l}7179.4 \\
5\end{array}$ & $\begin{array}{l}19142 . \\
63\end{array}$ & $\begin{array}{l}18348 . \\
30\end{array}$ & $\begin{array}{l}22556 \\
0.25\end{array}$ \\
\hline Cultivate forest & 29088 & $\begin{array}{l}22460 . \\
33\end{array}$ & $\begin{array}{l}23604 . \\
45\end{array}$ & $\begin{array}{l}27908 . \\
70\end{array}$ & $\begin{array}{l}30517 . \\
05\end{array}$ \\
\hline
\end{tabular}

To sum up, we can get the value of green GDP :

Table 10. the 2009-2013 Green GDP accounting value table of City A (Unit:Million yuan)

\begin{tabular}{|c|c|c|c|c|c|}
\hline Category & 2008 & 2009 & 2010 & 2011 & 2012 \\
\hline Traditional GDP & 65300100 & 79255800 & 100113700 & 114096000 & 126566900 \\
\hline \multicolumn{6}{|c|}{-Resource depletion cost } \\
\hline Coal & 384909.29 & 422065.56 & 466973.7 & 524797 & 492750 \\
\hline Natural gas & 105933.75 & 107498.31 & 122600.66 & 134291.4 & 154239.54 \\
\hline Oil & 3194.73 & 3231.61 & 4278.08 & 4282.69 & 4301.13 \\
\hline
\end{tabular}

-Environmental degradation

cost
Sulfur dioxide
Smoke dust
Industrial solid waste
+ (3)Resources and
nvironment improvement

Afforestation

Cultivate forest

Green GDP

The proportion of green GDP

$$
\text { in GDP }
$$

56113.20

7946.40

7295.40

7358.40

7450

7500

6700

1207.50

250
44054.40

$\begin{array}{llll}7179.45 & 19142.63 & 18348.30 & 225560.25\end{array}$

$\begin{array}{lllll}29088 & 22460.33 & 23604.45 & 27908.70 & 30517.05\end{array}$

$\begin{array}{lllll}64764694.83 & 78678985.3 & 99491835.04 & 113424604.8 & 126120023.8\end{array}$

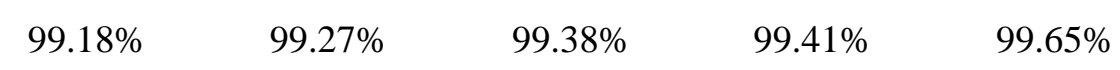


need to be further studied.The focus of this paper is to introduce the core idea of green GDP into environmental performance audit.I hope to conduct a comprehensive supervision, appraisal and evaluation of environmental performance audit in the perspective.

\section{Conclusion}

As a system of environmental accounting system, the green GDP method has a certain application value in environmental performance audit.The introduction of this method is to achieve the audit objectives in environmental performance audit.However, as a special auditing method, this method needs more improvement and innovation, so that it can be applied to environmental performance audit.For the audit standards of the results of its judgment, the research should also be carried out.

(the Research findings of Baoding Research Institute of low carbon development)

\section{REFERENCES}

[1] Wang defa.2008.green GDP : Environmental and economic accounting system and its application.shanghai:Shanghai University of Finance and Economics press.10-18

[2] Cheng dongjing, Li peiying, Wu sangyun.2008.Research on the evaluation of marine green GDP accounting and sustainable development.shandong:China business press,21-35

[3] Peng tao,Wu wenliang.2010.Green GDP accounting: Re study and re discussion on the background of low carbon development.China population,12(20):81-86

[4] Gao minxue.2004.Misunderstanding and discrimination of green GDP.Journal of Renmin University of China,3(3):56-62 